\title{
Tomato Shading Study- Las Vegas 2018 Results
}

\author{
Angela 0 Callaghan* \\ Specialist, Social Horticulture, University of Nevada, USA
}

*Corresponding author: Angela O Callaghan, Specialist, Social Horticulture, University of Nevada, Reno, USA.

Received Date: September 17, 2019

Published Date: September 23, 2019

\section{Abstract}

Cooperative Extension in southern Nevada has been recommending shading tomato plants in the summer to extend the season and help improve production as well as quality. The question remained "Does shading up tomatoes really help in such a harsh desert climate, and if so, how much shade? Do all tomato cultivars benefit equally?" This research aimed to obtain information that could be useful to small growers, including household growers, who must confront the in this region.

We selected four commonly grown tomato cultivars: Celebrity, Early girl, Heat Wave and Red Cherry (a very small-fruited variety). The treatments were, $0 \%, 30 \%$ and $50 \%$ shade. We transplanted seedlings into raised beds with organically amended soils. The land where the raised beds were located where plants had not grown previously. Major problems included wind damage, sunscald, herbivory and root knot nematodes.

The project had noticeable results, indicating that $30 \%$ shade gave the best yields. In the $50 \%$ shade treatment, the plants grew large, but had few blossoms or fruit. The high standard deviation made the 2018 results less than statistically significant. Despite the problems, the data will give guidance to growers.

\section{Introduction}

Whether growing in a large container on the patio or a row in the home vegetable garden, tomatoes are one of the most popular vegetables in the world, but growing tomatoes in the Mojave Desert is not easy. The average temperatures in summer range from $100^{\circ}-104^{\circ} \mathrm{F}\left(40^{\circ} \mathrm{C}\right)$. There is generally no rainfall during the summer. Heat, low humidity, salty infertile soil and intense sunlight all conspire to foil the home gardener. The choices for Mojave gardeners were either to let the plants die back around June, when weather conditions became extreme, or cut them back at that time, and water through the summer in the hope they revived when temperatures were again in the double digits.

Research on protection of tomatoes has concentrated on growth in greenhouses or other means of protected agriculture and use of different shade colors to improve crop quality [1,2]. While much research studies tomato growth in arid environments $[3,4]$, no research has been done on protecting tomatoes from the intense sunlight and other conditions found in the Mojave Desert.

\section{Materials and Methods}

\section{Location}

Center for Urban Water Conservation in North Las Vegas, NV (A collaboration of University of Nevada Cooperative Extension, UNLV, City of North Las Vegas, \& Bureau of Land Management). This site has several acres (hectares) of trees, vines, vegetables, green houses and shade houses in the Mojave Desert.

In addition, there is a large pool of Master Gardener volunteers on site, other research is occurring, and infrastructure exists, providing electricity and irrigation.

The site of the raised beds, however, was virgin desert soilsaline, infertile, pH over 8.

Design

- $\quad$ Nine beds, each $1.2 \mathrm{~m} \times 4.9 \mathrm{~m}$

- Wooden walls, depth 10"

- $\quad$ Each bed represented one treatment $(0 \%, 30 \%, 50 \%)$

- Three replicates

- $\quad$ Four plants per treatment (2018);

- $\quad$ Fill-standard raised bed fill

- Frames for shade cloth-schedule $40 \mathrm{pvc}$

\section{Plant material}

Seeds were obtained from Rimer seeds (a completely on-line company). Four commonly available varieties were tested: Early Girl, Celebrity, Heatwave, and Red Cherry. 


\section{Methods}

Plants were started from seed in an unheated greenhouse, transferred into $10 \mathrm{~cm}$ pots when four true leaves appeared, and planted in raised beds after the six true leaf stage (mid-May). Shade cloth was installed on June 2 (30 and 50\% shade).

\section{Results}

SPAD Readings were taken on all plant samples in June and July 2018. Among varieties and treatments, Celebrity and Early Girl displayed a significant SPAD increase only in the 30\% shade treatment from June to July. There was no significant difference with either Heatwave or Red Cherry (Table 1\&2).

Table 1: BRIX Readings were taken on a sample of fruits on day of harvest.

\begin{tabular}{|c|c|c|c|}
\hline Brix levels & \multicolumn{3}{|c|}{ August - November 2018 } \\
\hline Variety & $\mathbf{0 \%}$ & $\mathbf{3 0 \%}$ & $\mathbf{5 0 \%}$ \\
\hline Celebrity & 3.85 & 4.26 & 4.05 \\
\hline Early girl & 4.72 & 4.46 & 5.43 \\
\hline Heatwave & 3.81 & 4.02 & 3.99 \\
\hline Red Cherry & 5.41 & 5 & 5.26 \\
\hline
\end{tabular}

Table 2: YIELDS The 2018 harvest began in August, which is late for this part of the country, and continued to November 1.

\begin{tabular}{|c|c|c|c|}
\hline \multicolumn{4}{|c|}{ Total Marketable Fruits August - November $\mathbf{2 0 1 8}$} \\
\hline Variety & $\mathbf{0 \%}$ & $\mathbf{3 0 \%}$ & $\mathbf{5 0 \%}$ \\
\hline Celebrity & 36 & 85 & 26 \\
\hline Early girl & 11 & 79 & 47 \\
\hline Heatwave & 47 & 97 & 46 \\
\hline Red Cherry & 92 & 81 & 68 \\
\hline
\end{tabular}

\section{Problems}

As mentioned above, the soil had not previously been used for any agriculture. Like many Southern Nevada soils, it is infertile, salty and alkaline with very poor structure. For this reason, raised beds were the method of choice. Unfortunately, they were built only $20 \mathrm{~cm}$. high, when they probably should have been twice that. Although they were filled with raised bed mix, they were still affected by the challenging conditions of the soil below.

Herbivory was a major problem. Birds, such as quail and mockingbirds, attacked fruits, as did rats and cottontail rabbits.
Root knot nematode afflicted all varieties, but most particularly Early Girl and Red Cherry. All cultivars were susceptible to ground squirrel damage to roots. In fact, all 2019 varieties were destroyed by ground squirrels by mid-august.

In order to promote pollination of fruit trees at the Center, beehives were located not far from the raised beds. All beehives became Africanized over late spring, and access to the experimental site was limited until the hives could be removed and replaced.

\section{Discussion}

Despite a host of problems, the trials indicated that shade treatments do make a difference when growing tomatoes in the Mojave Desert's harsh climate. The number of marketable fruits was significantly higher under the $30 \%$ shade treatment for all except the Red Cherry variety. Under the $50 \%$ shade treatment, all varieties produced the fewest number of marketable fruits. These plants grew the largest, however, indicating that the high shade level interfered with flower, but not foliar, production.

Varietal differences appeared in the BRIX data as well. Celebrity and Heatwave displayed the highest sugar levels under the $30 \%$ shade treatment; Early Girl tomatoes were sweetest under 50\% shade, but unshaded Red Cherry tomatoes had the highest sugar levels.

\section{Acknowledgement}

None.

\section{Conflict of Interest}

No conflict of interest.

\section{References}

1. López D, Carazo N, Rodrigo MC, Garcia J (2007) Coloured Shade Nets Effects on Tomato Crops Quality. Acta Hortic 747(747): 121-124.

2. DD Nangare, Jitendra Singh, VS Meena, Bharat Bhushan, PR Bhatnagar (2005) Effect of green shade nets on yield and quality of tomato (Lycopersicon esculentum Mill) in semi-arid region of Punjab. Asian Journal of Advances in Basic and Applied Science 2015: 1(1): 1-8.

3. Maughan Tiffany, Drost Dan, Black Brent, Day Sam (2017) Using Shade for Fruit and Vegetable Production. All Current Publications Paper 1654.

4. Panigrahi, Thalesh Kumar, Kujur, Amit Nishant, Singh Nutan (2015) Common Physiological Disorder of Tomato (Solanum Lycopersicum). Journal of Plant Development Sciences 7(5): 465-468. 